\title{
ANALISIS PENGARUH KONTRAK PSIKOLOGIS DAN KOMITMEN ORGANISASI TERHADAP KINERJA KARYAWAN
}

\author{
Stevan Asalamtama Purba ${ }^{a}$ \\ Bandar Lampung, Lampung \\ gerstevan@gmail.com \\ Ribhan $^{\mathrm{b}}$, Mirwan Karimc \\ Jurusan Manajemen, Fakultas Ekonomi dan Bisnis, Universitas Lampung. \\ ribhan@feb.unila.ac.id ${ }^{b}$,Mirwan.Karim@yahoo.com ${ }^{c}$
}

\begin{abstract}
ABSTRAK
Pada saat ini hampir seluruh perusaahan di dunia berusaha untuk membangun nilai yg berbeda dan berkelanjutan dengan cara meningkatkan aset yg tidak dapat di ukur dengan uang, seperti sumber daya manusia, teknologi dan organisasi. Oleh kerena itu kemampuan sumber daya Indonesia perlu di tingkatkan secara terus menerus. Tujuan penelitian ini yaitu untuk mengetahui pengaruh kontrak psikologis dan komitmen organisasi terhadap kinerja karyawan PT. Sari Segar Husada Lampung Selatan. Penelitian ini menggunakan sampel dengan jumlah sampel 277 responden. Alat analisis dalam penelitian ini menggunakan regresi berganda dengan program SPSS.

Hasil penelitian ini mendukung hipotesis yang di ajukan, yaitu Kontrak Psikologis dan Komitmen Organisasi berpengaruh positif dan signifikan terhadap kinerja karyawan PT. Sari Segar Husada Lampung Selatan. Saran bagi pihak PT. Sari Segar Husada Lampung Selatan adalah perbaikan pada bagian kontrak psikologis dalam organisasi ataupun perusahaan dapat dengan meningkatkan insentif ataupun tunjangan sesuai beban kerja karyawan. Perusahaan dapat megupayakan peningkatan komitmen organisasi pada setiap karyawan dengan memacu dan memotivasi karyawan, serta menumbuhkan rasa solidaritas dalam perusahaan sehingga dapat memacu karyawan untuk tetap mempertahankan karyawan berkompeten dalam perusahaan.
\end{abstract}

Kata Kunci : Kontrak Psikologis, Komitmen Organisasi dan Kinerja

\begin{abstract}
At present, almost all companies in the world are trying to build a different and sustainable value by increasing assets that cannot be measured by money, such as human resources, technology and organizations. Because of this, the ability of Indonesian resources needs to be improved continuously. The purpose of this study is to determine the effect of psychological contracts and organizational commitment to the performance of employees of PT. Sari Segar Husada, South Lampung. This study uses a sample of 277 respondents. The analytical tool in this study uses multiple regression with the SPSS program.

The results of this study support the proposed hypothesis, that is Psychological Contracts, and Organizational Commitment has a
\end{abstract}


positive and significant effect on the performance of employees of PT. Sari Segar Husada, South Lampung. Suggestions for PT. Sari Segar Husada, South Lampung, is an improvement on the psychological contract part of the organization or company by increasing incentives or benefits according to employee workload. Companies can seek to increase organizational commitment to every employee by encouraging and motivating employees, as well as fostering a sense of solidarity within the company so that it can spur employees to keep competent employees in the company.

Keywords: Psychological Contract, Organizational Commitment, and Performance.

\section{PENDAHULUAN}

Era globalisasi saat ini persaingan antar perusahaan semakin bertambah, setiap perusahaan saling berusaha menjadi yang terbaik. Tidak ada satu perusahaan yang ingin dikalahkan oleh para pesaingnya. Setiap perusahaan terus berupaya meningkatkan perusahaannya ke level yang lebih tinggi maupun mempertahankannya, baik itu perusahaan milik negara maupun perusahaan swasta selalu berupaya menjaga kepercayaan atas produk yang dihasilkan untuk mencapai tujuan tersebut, perusahaan sangat membutuhkan sumber daya manusia yang berkualitas. Sumber daya manusia pada hakekatnya merupakan salah satu modal dan memegang suatu peran yang paling penting dalam mencapai tujuan perusahaan. Oleh karena itu perusahaan perlu mengelola sumber daya manusia sebaik mungkin. Sebab kunci sukses suatu perusahaan bukan hanya pada keunggulan teknologi dan tersedianya dana saja. Sumber daya manusia merupakan aset yang paling penting dalam suatu organisasi atau perusahaan.

Perusahaan yang berhasil adalah perusahaan yang memiliki sumber daya manusia dengan kinerja yang baik sehingga dapat menghasilkan pekerjaan yang baik pula. Orang cakap adalah orang yang berprestasi baik. Berprestasi baik di sini menjelaskan bahwa ketika seorang karyawan dapat menyelesaikan semua pekerjaan dengan cepat dan akurat maka karyawan tersebut dikatakan berprestasi dan dapat berkembang untuk kelangsungan perusahaan ke depannya. Kinerja yang rendah akan menimbulkan berbagai dampak negatif seperti, mangkir kerja, kerja lamban, dan berhenti kerja. Hal ini berakibat pada kerugian bagi karyawan walaupun dampak kerugiannya tidak terlalu nampak jelas. Sebaliknya kinerja yang tinggi sangat mempengaruhi kerja yang positif sehingga mampu memberikan keuntungan nyata, tidak hanya bagi perusahaan tetapi juga keuntungan bagi karyawan itu sendiri (Maslan, 2011).

Tinggi rendahnya kinerja seorang karyawan dapat diketahui dengan suatu pengukuran dan penilaian kinerja, yaitu dengan melakukan pengukuran dan penilaian kinerja. pengukuran kinerja adalah menetapkan kriteria, langkah selanjutnya ialah mengumpulkan informasi yang berhubungan dengan hal tersebut selama periode tertentu. Setelah itu membandingkan hasil tersebut dengan target yang dibuat untuk periode yang sama, sehingga didapatkan suatu tingkat kinerja dari seseorang yang sedang diukur.

Sedangkan penilaian kinerja merupakan evaluasi dari pimpinan terhadap kinerja pegawai atu karyawan supaya hasil yang diharapkan perusahaan dapat tercapai. Ketika dilaksanakan pengukuran dan penilaian kinerja karyawan, perusahaan harus melihat beberapa faktor yang menjadi acuan dalam mempengaruhi kinerja karyawannya. 
Perusahaan mengharapkan agar memiliki karyawan yang mau dan mampu untuk melaksanakan tugasnya dengan baik, bahkan lebih baik dari yang diharapkan. Oleh karena itu, sangat diperlukan komunikasi yang baik pula antar karyawan yang dapat saling membantu dan bekerja sama. Fokus dari kontrak psikologis adalah bagaimana membangun kondisi yang kondusif bagi karyawan. Kontrak psikologis tersebut merupakan rangsangan dan motivator untuk karyawan untuk semakin terikat dengan pekerjaan maupun perusahaannya. Menurut penelitian Bhatnagar (2007) lebih dari decade terakhir, banyak studi menunjukkan dukungan empiris pada kontrak psikologis sebagai motivator penting untuk karyawan.

Perusahaan harus dapat menunjang fungsi dari kontrak psikologis yang optimal, dalam pelaksanaannya seringkali perusahaan mengalami hambatan, misal timbulnya ketidakpuasan karyawan dalam menyelesaikan pekerjaan. Untuk meminimalisir adanya ketidakpuasan pada diri karyawan, perusahaan seharusnya dapat mengabulkan harapan karyawan atau memberikan kontribusi berdasarkan kebutuhannya, dikarenakan apabila perusahaan dapat memberikan kompensasi yang sesuai dengan kebutuhan karyawan, maka karyawan termotivasi untuk menghasilkan kinerja yang lebih baik. Timbulnya motivasi karyawan tersebut juga dapat mempengaruhi timbulnya komitmen karyawan pada perusahaan. .

Komitmen organisasi merupakan faktor penting dalam perusahaan, karena dapat berpengaruh terhadap perilaku yang berhubungan dengan pekerjaan yang positif, misalnya kinerja yang tinggi, loyalitas karyawan, dan turnover yang rendah. Berdasarkan uraian latar belakang masalah di atas, maka permasalahan dalam penelitian ini akan dirumuskan sebagai berikut :

1. Apakah kontrak psikologi berpengaruh terhadap kinerja karyawan?

2. Apakah komitmen organisasi berpengaruh terhadap kinerja karyawan ?

\section{TINJAUAN PUSTAKA DAN PENGEMBANGAN HIPOTESIS}

\section{Kontrak Psikologis}

kontrak psikologis tidak tertulis di atas kertas dan tidak semua ketentuannya dinegosiasikan secara eksplisit antara individu dengan organisasi. Menurut Rousseau (2000) mendefinisikan kontrak psikologi sebagai persepsi karyawan tentang perwujudan dan kewajiban timbal balik terhadap perusahaan dan saling menguntungkan. Menurut Schein (2010) menyatakan kontrak psikologis adalah suatu harapan yang dimiliki masing-masing pihak, karyawan dan perusahaan, terhadap yang lainnya dan kewajiban yang dimiliki oleh dan kepada satu pihak dengan pihak lain. Kontrak psikologis ini sering dipahami dari sudut pandang karyawan bukan dari sudut pandang perusahaan.

Kesepakatan baik barang nyata (seperti upah, benefit, produktivitas tenaga kerja, dan kehadiran) maupun barang tidak nyata (seperti kesetiaan, perlakuan adil, dan keamanan kerja) tercakup dalam kontrak psikologis antara tenaga kerja dan pemberi kerja. Banyak perusahaan berusaha menjelaskan dengan rinci harapan mereka melalui buku pedoman tenaga kerja dan pedoman kebijakan, namun materi tersebut hanyalah sebagian dari hubungan kontraktual secara keseluruhan.

Karyawan memiliki harapan kepada organisasi mereka dalam kaitannya dengan faktor seperti promosi, gaji, dan pengembangan karir. Di sisi lain, perusahaan mengharapkan kemauan untuk bekerja, loyalitas, dan keterlibatan kerja dari karyawan. Sehingga ada hubungan timbal balik antara karyawan dan perusahaan tersebut, apabila karyawan bekerja dengan baik dan mendukung kemajuan perusahaan maka perusahaan juga akan memenuhi harapan karyawan berkaitan dengan pemberian gaji. 
Uraian di atas dapat disimpulkan bahwa kontrak psikologis didefinisikan dalam bentuk kontribusi dari individu terhadap organisasi. Individu memberikan beragam kontribusi seperti upaya, keahlian, kemampuan, waktu, kesetiaan, dan lain-lain untuk organisasi. Sebagai imbalan untuk kontribusi ini, organisasi memberikan insentif kepada karyawan. Sejumlah insentif, seperti gaji, dan peluang pengembangan karir adalah balas jasa berwujud. Insentif- insentif lain, seperti jaminan kerja dan status bersifat tidak berwujud.

Menurut Rousseau (2000) menekankan bahwa aspek kontrak psikologis mengacu pada keyakinan tentang janji- janji organisasi kepada karyawannya atas kontribusi mereka terhadap organisasi ketika kinerja mereka baik, seperti pengembangan karir karyawan, penawaran posisi pekerjaan yang terbaik kepada karyawan, lingkungan sosial pekerjaan yang menyenangkan, gaji yang setara dengan pekerjaan karyawan.

Ketika organisasi memenuhi kewajibannya terhadap karyawan maka karyawan akan berkontribusi sepenuhnya terhadap organisasi dengan menyeimbangkan masalah pribadi dengan masalah di dalam organisasi, keluwesan karyawan dalam bekerja, loyalitas karyawan terhadap organisasi, perilaku karyawan yang baik kepada sesama maupun atasannya, dan ketersediaan karyawan berkerja dengan maksimal (Rousseau 2000).

Kontrak psikologis merupakan hubungan antara organisasi dengan karyawan, ketika suatu organisasi mampu memenuhi harapan karyawan tentang pengembangan karir, penawaran pekerjaan yang menarik, lingkungan kerja yang baik, pembayaran gaji yang sepadan, menghorrmati dan memahami keadaan pribadi karyawan maka karyawan juga akan bersedia memberikan wujud timbal balik kepada perusahaan. Timbal balik tersebut seperti memberikan kualitas kerja yang baik, kesediaan untuk bekerja lembur, lebih loyal terhadap perusahaan, berperilaku baik, jujur, dan menjaga nama baik perusahaan, dan bersedia melakukan tugas yang diberikan organisasi (Rousseau 2000). Menurut Rousseau (2000) kontrak psikologis dibagi kedalam dua bentuk yaitu :

\section{a. Transactional Contract}

Transactional contract atau kontrak transaksional merupakan bentuk perjanjian jangka pendek dan berfokus pada aspek pertukaran ekonomis (uang) dengan jenis pekerjaan yang sempit dan keterlibatan karyawan yang sedikit dalam organisasi. Oleh karena itu hubungan yang terjalin dibangun tidak berdasarkan jangka waktu bekerja yang lama. Hubungan kerja dalam kontrak transaksional akan berakhir ketika kinerja karyawan dianggap buruk atau kontrak tertulis berakhir. Terdapat dua dimensi utama dalam kontrak transaksional, yaitu (Rousseau 2000):

1) Narrow, yaitu karyawan hanya diwajibkan melakukan pekerjaan yang sesuai dengan perintah organisasi. Organisasi membatasi keterlibatan karyawan dalam organisasi dan memberikan kesempatan terbatas untuk pelatihan dan pengembangan

2) Short term, karyawan tidak memiliki kewajiban untuk tetap bekerja di organisasi selamanya dan berkomitmen untuk bekerja hingga batas waktu tertentu. Organisasi menawarkan hubungan kerja yang hanya untuk jangka waktu tertentu dan tidak berkewajiban untuk menjamin karir karyawan jangka panjang.

\section{b. Relational Contract}

Relational contract atau kontrak relasional memiliki jangka waktu yang panjang dan berakhirnya tidak dapat ditentukan. Jenis kontrak ini juga melibatkan faktor sosioemosional seperti kepercayaan, keamanan dan loyalitas. Terdapat dua dimensi kontrak relasional yaitu (Rousseau 2000) :

1) Stability, karyawan diwajibkan untuk bekerja pada organisasi untuk jangka waktu yang relatif lama dan melakukan hal-hal lain untuk mempertahankan pekerjaannya. Organisasi dalam hal ini menawarkan kompensasi yang stabil dan hubungan kerja jangka panjang.

2) Loyalty, karyawan diwajibkan untuk mendukung organisasi, menunjukkan kesetiaan 
dan komitmen terhadap kebutuhan dan kepentingan organisasi. Selain itu, karyawan diharapkan menjadi anggota organisasi yang baik. Sebaliknya organisasi memberikan komitmen untuk menjamin kesejahteraan dan kebutuhan karyawan beserta keluarganya.

\section{c. Balanced}

Balanced merupakan bentuk perjanjian yang dinamis dan terbuka, dikondisikan pada keberhasilan ekonomi perusahaan dan kesempatan pekerja untuk mengembangkan keuntungan karir. Pekerja dan perusahaan berkontribusi besar untuk belajar dan pengembangan masing-masing. Imbalan kepada pekerja didasarkan pada kinerja dan kontribusi untuk perusahaan, terutama dalam menghadapi perubahan tuntutan karena tekanan pasar. Terdapat tiga dimensi dalam kontrak yang seimbang, yaitu (Rousseau 2000) :

1) External employabilit, yaitu pengembangan karir pada tenaga kerja eksternal. Karyawan diwajibkan untuk mengembangkan keterampilan berharganya. Perusahaan telah berkomitmen untuk meningkatkan kerja jangka panjang pekerja di luar organisasi serta didalamnya.

2) Internal advancement, yaitu karir dalam pasar tenaga kerja internal. Karyawan diwajibkan untuk mengembangkan keterampilan yang dihargai oleh perusahaan saat ini. Perusahaan telah berkomitmen untuk menciptakan peluang pengembangan karir pekerja dalam perusahaan.

3) Dynamic performance, yaitu karyawan wajib untuk berhasil melakukan hal baru dan tujuan yang lebih menuntut, yang dapat berubah di masa depan, untuk membantu perusahaan menjadi tetap kompetitif. Perusahaan telah berkomitmen untuk mempromosikan pembelajaran terus menerus untuk membantu karyawan berhasil mengeksekusi dan meningkatkan standar kinerja.

d. Transitional

Transitional merupakan bukan kontrak psikologis yang terbentuk sendiri, tapi kognitif menyatakan konsekuensi dari perubahan organisasi dan transisi yang berada bertentangan dengan pengaturan kerja yang ditetapkan sebelumnya. Terdapat tiga dimensi kontrak transisi, yaitu (Rousseau 2000) :

1) Mistrust, karyawan percaya bahwa perusahaan tidak konsisten dalam mengirimkan sinyal niat; karyawan tidak percaya kepada perusahaan. Persahaan menyembunyikan informasi penting dari karyawan. Perusahaan tidak percaya terhadap pekerjanya.

2) Uncertainly, karyawan tidak pasti mengetahui sifat kewajibannya sendiri bagi perusahaan. Perusahaan mengukur dan menilai karyawan yang tidak pasti mengenai komitmen masa depan perusahaan kepadanya.

3) Erosion, karyawan mengharapkan untuk menerima lebih sedikit keuntungan masa mendatang darinya kontribusi untuk perusahaan dibandingkan dengan masa lalu; mengantisipasi penurunan terus di masa depan. Perusahaan memiliki perubahan yang mengurangi upah karyawan dan manfaat, mengikis kualitas kehidupan kerja dibandingkan dengan tahun-tahun sebelumnya.

Dari uraian di atas, terdapat perbedaan antara kontrak transaksional dan kontrak relasional. Kontrak transaksional dikarakteristikan dengan perjanjian yang bersifat moneter dengan

\section{Komitmen Organisasi}

Menurut Meyer \& Allen (1991) menyatakan bahwa komitmen organisasi adalah perasaan dedikasi untuk mempekerjakan seseorang di organisasi, kemauan untuk bekerja keras untuk majikan dan maksud untuk tetap dengan organisasi itu. Komitmen pada organisasi didefinisikan sebagai suatu keadaan dimana seorang karyawati memihak pada 
suatu organisasi tertentu dan tujuan-tujuannya, serta berniat memelihara keanggotaan dalam organisasi itu. Robbins \& Judge (2008) mendefinisikan komitmen organisasi sebagai suatu keadaan dimana seorang individu memihak organisasi serta tujuan-tujuan dan keinginannya untuk mempertahankan keanggotaannya dalam organisasi. Sedangkan Mathis \& Jackson (2006) mendefinisikan komitmen organisasi sebagai tingkat sampai di mana karyawan yakin dan menerima tujuan organisasional, serta berkeinginan untuk tetap tinggal bersama organisasi.

Komitmen organisasi merupakan faktor yang mempengaruhi diri individu pada suatu organisasi. Karyawan dianggap berkomitmen untuk sebuah organisasi jika mereka rela melanjutkan hubungan mereka dengan organisasi dan mengabdikan diri untuk mencapai tujuan organisasi. Tingginya tingkat usaha yang diberikan oleh karyawan dengan tingkat komitmen organisasi akan menyebabkan tingkat yang lebih tinggi dari kinerja dan efektivitas baik individu dan tingkat organisasi dari sudut pandang sikap, komitmen organisasi didefinisikan sebagai (1) keinginan kuat untuk tetap sebagai anggota organisasi tertentu, (2) keinginan untuk berusahan keras sesuai keinginan organisasi, (3) keyakinan tertentu dan penerimaan nilai dan tujuan organisasi (Luthans, 2005). Dengan kata lain, komitmen organisasi ini merupakan sikap yang merefleksikan loyalitas karyawanpada organisasi dan proses berkelanjutan dimana anggota organisasi mengekspresikan perhatiannya terhadap organisasi dan keberhasilan serta kemajuan yang berkelanjutan. Komitmen organisasi sebagai :"The relative strength of an individuals identification with and involvement in a particular organization. " Definisi ini menunjukkan bahwa komitmen organisasi memiliki arti yang lebih luas dari sekadar loyalitas yang pasif, tetapi melibatkan hubungan interaktif dan keinginan karyawan untuk memberikan kontribusi yang berarti pada organisasinya.

Dari beberapa definisi di atas dapat disimpulkan bahwa komitmen organisasi merupakan sifat hubungan antara individu dengan organisasi, dimana individu mempunyai keyakinan diri terhadap nilai-nilai dan tujuan organisasi, adanya kerelaan untuk menggunakan usahanya secara sungguh-sungguh demi kepentingan organisasi, serta mempunyai keinginan yang kuat untuk tetap menjadi bagian dari organisasi tersebut. Berikut jenis-jenis komitmen organisasi menurut Allen dan Mayer (1990) adalah:

1) Komitmen Afektif (affective commitment)

Affective commitment berkaitan dengan hubungan emosional anggota terhadap organisasinya, identifikasi dengan organisasi, dan keterlibatan anggota dalam kegiatan berorganisasi. Anggota organisasi dengan affective commitment yang tinggi akan terus menjadi anggota dalam organisasi karena memang memiliki keinginan untuk itu.

2) Komitmen Berkelanjutan (continuance commitment)

Continuance commitment berkaitan dengan kesadaran anggota organisasi akan mengalami kerugian jika meninggalkan organisasi. Anggota organisasi dengan continuance commitment yang tinggi akan terus menjadi anggota dalam organisasi karena mereka memiliki kebutuhan untuk menjadi anggota organisasi tersebut.

3) Komitmen Normatif (normative commitment)

Normative commitment menggambarkan perasaan keterikatan untuk terus berada dalam organisasi. Anggota organisasi dengan normative commitment yang tinggi akan terus menjadi anggota dalam organisasi karena merasa dirinya harus berada dalam organisasi tersebut.

Faktor-faktor yang mempengaruhi komitmen organisasi menurut Allen dan Meyer (1997).

1. Karakteristik pribadi individu Karakteristik pribadi individu terbagi ke dalam dua variabel yaitu:

a. Variabel demografis 
Variabel demografis mencakup gender, usia, status pernikahan, tingkat pendidikan, dan lamanya seseorang bekerja pada suatu organisasi, dalam beberapa penelitian ditemukan adanya hubungan antara variabel demografis tersebut dan komitmen berorganisasi.

b. Variabel disposisional

Variabel disposisional mencakup kepribadian dan nilai yang dimiliki anggota organisasi. Hal-hal lain yang tercakup ke dalam variabel disposisional ini adalah kebutuhan untuk berprestasi dan etos kerja yang baik serta kebutuhan untuk berafiliasi dan persepsi individu mengenai kompetensinya sendiri. Variabel disposisional ini memiliki hubungan yang lebih kuat dengan komitmen berorganisasi, karena adanya perbedaan pengalaman masing-masing anggota dalam organisasi tersebut.

2. Karakteristik organisasi Termasuk dalam karakteristik organisasi yaitu struktur organisasi, desain kebijaksanaan dalam organisasi, dan bagaimana kebijaksanaan organisasi tersebut disosialisasikan.

3. Pengalaman selama berorganisasi Pengalaman berorganisasi tercakup ke dalam kepuasan dan motivasi anggota organisasi selama berada dalam organisasi, perannya dalam organisasi tersebut, dan hubungan antara anggota organisasi dengan supervisor atau pemimpinnya.

\section{Kinerja Karyawan}

Menurut Koopmans, et al. (2014) kinerja adalah ukuran dari hasil yang relevan berdasarkan penelitian dalam pengaturan kerja. Penilaian kinerja difokuskan baik dalam ukuran objektif yaitu dari produktivitas kerja seperti absensi, jumlah tindakan tertentu ataupun output yang dipelihara dan berada dalam catatan organisasi ataupun dalam penilaian subjektif yaitu dari kuantitas dan kualitas pekerjaan dari masing-masing karyawan. Dikatakan juga bahwasannya kinerja adalah tindakan terukur, baik perilaku dan hasil bahwa karyawan terlibat ataupun berkontribusi dalam tujuan organisasi.

Kinerja merupakan prestasi kerja, yaitu perbandingan antara hasil kerja dengan standar yang ditetapkan. Prestasi kerja karyawan telah didefinisikan sebagai kinerja dalam hal kuantitas dan kualitas yang diharapkan dari setiap karyawan. Kinerja pada dasarnya apa yang dilakukan atau tidak dilakukan oleh karyawan. Kinerja karyawan yang umum untuk pekerjaan meliputi kuantitas dari hasil, kualitas dari hasil, ketepatan waktu dari hasil, kehadiran, dan kemampuan bekerja sama. Mathis dan Jackson (2006). Dalam hal ini kriteria pekerjaan adalah faktor paling penting yang dilakukan orang dalam pekerjaan mereka karena berkaitan dengan apa yang diberikan organisasi untuk dilakukan oleh karyawan.

Peningkatan kinerja merupakan hal yang diinginkan baik dari pihak pemberi kerja maupun para pekerja. Perusahaan menginginkan kinerja karyawannya baik, karena kinerja karyawan yang baik dapat meningkatkan produktivitas perusahaan. Disisi lain, para pekerja berkepentingan untuk mengembangkan diri dan promosi pekerjaan, jadi dapat disimpulkan bahwa kinerja adalah keluaran yang dihasilkan suatu pekerjaan atau suatu profesi dalam waktu tertentu yang diukur melalui hasil kerja, perilaku kerja, dan sifat pribadi yang berhubungan dengan pekerjaan. Berhasil tidaknya kinerja yang telah dicapai oleh organisasi dipengaruhi oleh tingkat kinerja dari karyawan secara individu maupun kelompok. Dengan peningkatan kompetisi, perusahaan telah mengakui pentingnya kinerja karyawan untuk bersaing di pasar global karena kinerja karyawan yang meningkat, itu akan mempengaruhi kinerja perusahaan dan profitabilitas perusahaan.

Menurut Koopmans, et al. (2014) indikator yang perlu dipertimbangkan dalam mengevaluasi kinerja meliputi :

1) Kinerja tugas 
Mengacu pada kemampuan seorang karyawan untuk melakukan tugas yang utama, yang meliputi kualitas kerja, perencanaan dan tugas pengorganisasian, berorientasi pada hasil, memprioritaskan, dan bekerja secara efisien.

2) Kinerja kontekstual

Mengacu pada perilaku karyawan yang mendukung organisasi, dan lingkungan psikologis sosial di mana tugas pekerjaan sentral dilakukan, misalnya bertanggung jawab untuk pekerjaan, memiliki inisiatif, senang untuk mengambil pekerjaan yang menantang, berkomunikasi efektif, mampu bekerja sama, dan untuk menerima dan belajar dari orang lain.

3) Perilaku kerja kontraproduktif

Mengacu pada perilaku yang berbahaya bagi kelangsungan hidup organisasi, misalnya, melakukan hal-hal yang merugikan organisasi, untuk melakukan hal-hal yang merugikan rekan kerja dan atasan, dan sengaja membuat kesalahan.

\section{Pengembangan Hipotesis}

Hipotesis merupakan jawaban sementara terhadap rumusan masalah penelitian, oleh karena itu rumusan masalah penelitian biasanya disusun dalam bentuk kalimat pertanyaan. Kontrak psikologis adalah serangkaian ekspektasi yang dimiliki seorang individu menyangkut apa yang akan dia kontribusikan untuk organisasi dan apa yang akan diberikan oleh organisasi sebagai balas. Tsui. , et. al. (2013) melakukan penelitian dengan hasil yang menunjukkan bahwa ada hubungan yang positif dan signifikan antara kontrak psikologis dengan kinerja karyawan. Penelitian serupa dilakukan oleh Steven (2013) hasil penelitian juga menyatakan bahwa kontrak psikologis memiliki pengaruh yang positif terhadap kinerja karyawan. Semakin baik kontrak psikologis karyawan maka kinerja karyawan juga akan meningkat. Apabila karyawan memiliki kontrak psikologis yang tinggi, misalnya merasa bahwa harus memberikan kontribusi yang lebih untuk perusahaan maka akan meningkatkan kinerjanya sebagai wujud timbal balik karena perusahaan telah memenuhi harapan dan kebutuhan yang diinginkannya. Oleh karena itu, hipotesis yang akan diajukan peneliti adalah

H1: Kontrak psikologis berpengaruh positif dan signifikan terhadap kinerja karyawan PT. Sari Segar Husada

Komitmen organisasi adalah perasaan dedikasi untuk mempekerjakan seseorang di organisasi, kemauan untuk bekerja keras untuk majikan, dan maksud untuk tetap dengan organisasi itu. Yeliz S. , et. al. (2013), melakukan penelitian dengan hasil menunjukkan bahwa ada hubungan yang positif dan signifikan antara komitmen organisasi dan kinerja. Peneliti lain seperti Chaoping (2013), melakukan penelitian dengan hasil menunjukkan bahwa ada hubungan yang positif dan siginifikan antara komitmen organisasi dengan kinerja karyawan. Ini karena karyawan merasa ada keamanan pekerjaan dan pemberian gaji yang stabil sehingga karyawan dapat memberikan hasil kerja yang lebih tinggi. Apabila organisasi tempat mereka bekerja saat ini adalah organisasi yang baik, seperti mensejahterakan dalam hal kebutuhan ekonominya, dan organisasi yang memberikan rasa nyaman pada pekerjaannya, maka karyawan akan memiliki rasa komitmen yang tinggi dan akan setia terhadap perusahaan sehingga karyawan harus bekerja dengan sungguh-sungguh dan meningkatkan kinerjanya demi kemajuan organisasi. Oleh karena itu, hipotesis yang diajukan peneliti adalah:

$\mathrm{H} 2$ : Komitmen organisasi berpengaruh positif dan signifikan terhadap kinerja karyawan PT. Sari Segar Husada 


\section{METODE PENELITIAN}

Penelitian ini merupakan penelitian kuantitatif. Penelitian kuantitatif yaitu metode penelitian yang berlandaskan pada filsafat positivism, digunakan untuk meneliti pada populasi atau sampel tertentu, teknik pengambilan sampel pada umumnya dilakukan secara random, pengumpulan data menggunakan instrumen penelitian, analisis data bersifat kuantitatif atau statistik dengan tujuan untuk menguji hipotesis yang telah ditetapkan. Jenis data yang digunakan dalam penelitian ini adalah data kuantitatif dan kualitatif. Sumber data yang digunakan dalam penelitian ini adalah data primer dan sekunder.

Data primer adalah informasi yang diperoleh dari tangan pertama oleh peneliti yang berkaitan dengan variabel yang diteliti berdasarkan sifatnya, data primer dibagi menjadi dua macam yaitu:

a. Data kualitatif, bersifat tidak berstruktur sehingga variasi data dari sumbernya mungkin sangat beragam. Hal ini disebabkan karena para karyawan yang terlibat dalam penelitian ini diberi kebebasan untuk mengutarakan pendapat. Data ini diperoleh langsung dari PT. Sari Segar Husada seperti gambaran umum perusahaan, hasil pengisian kuesioner dan data lainnya yang dapat menunjang penelitian ini.

b. Data kuantitatif, bersifat terstruktur sehingga mudah dibaca peneliti. Data kuantitatif adalah data yang dapat dihitung berupa angka-angka yang diperoleh langsung dari PT. Sari Segar Husada seperti jumlah karyawan, absensi karyawan dan data lainnya yang dapat menunjang penelitian ini.

Data sekunder adalah informasi yang diperoleh dari sumber yang telah ada atau dari penelitian sebelumnya, seperti dari web, internet, catatan atau dokumentasi perusahaan, dan studi kepustakaan terkait dengan topik penelitian. Data sekunder dibagi menjadi dua, yaitu

a. Data internal

Data internal yaitu data yang sifatnya intern atau dari dalam perusahaan yang bersangkutan.

b. Data eksternal

Data eksternal yaitu data yang sifatnya eksternal atau data yang telah disediakan oleh pihak tertentu diluar perusahaan.

Populasi dalam penelitian ini adalah seluruh karyawan PT Sari Segar Husada sebanyak 900 orang. Sampel adalah bagian dari jumlah dan karakteristik yang dimiliki oleh populasi. Dengan demikian sampel adalah sebagian dari populasi yang karakteristiknya hendak diselidiki, dan bisa mewakili keseluruhan populasinya sehingga jumlahnya lebih sedikit dari populasi. Besar sampel yang digunakan dapat dihitung dengan rumus Slovin. Dalam penelitian ini sampel yang digunakan sebanyak 277 responden.

Metode yang digunakan dalam pengambilan sampel adalah metode non- probability sampling dengan teknik Purposive Sampling (Judgement Sampling) yaitu sampel yang dipilih dengan cermat sehingga relevan dengan rancangan penelitian. Purposive Sampling yaitu cara pengambilan sampel yang didasarkan pada pertimbangan-pertimbangan tertentu, terutama pertimbangan yang dberikan oleh pakar atau expert. Teknik ini merupakan teknik pemilihan sampel berdasarkan ciri-ciri khusus yang dimiliki sampel tersebut yang dipertimbangkan memiliki hubungan yang sangat erat ciri- ciri populasi yang sudah di ketahui sebelumnya.

Variabel penelitian merupakan salah satu hal terpenting dalam setiap penelitian, variabel penelitian ditentukan berdasarkan masalah yang ada di lapangan setelah survey dilakukan. Penjelasan ini mengenai variabel penelitian dan definisi operasional variabel sebagai berikut:

Variabel penelitian yang digunakan dalam penelitian ini adalah: 


\section{a. Variabel bebas (independent variabel)}

Variabel bebas adalah variabel yang mempengaruhi, yang menyebabkan timbulnya atau berubahnya variabel terikat. Variabel bebas yang digunakan dalam penelitian ini adalah kontrak psikologis dan komitmen organisasi.

\section{b. Variabel terikat (dependent variabel)}

Variabel terikat adalah variabel yang dipengaruhi karena adanya variabel bebas. Variabel terikat yang digunakan dalam penelitian ini adalah kinerja

Metode pengumpulan data merupakan bagian integral dari desain penelitian untuk memperoleh data dan informasi yang diperlukan dalam skripsi. Metode yang digunakan peneliti adalah metode kuesioner yaitu daftar pertanyaan tertulis yang dirumuskan sebelumnya yang akan dijawab oleh responden. Menggunakan alternatif jawaban yang sama untuk berbagai macam pertanyaan membuat responden dapat memberikan jawaban terhadap berbagai macam pertanyaan dalam waktu yang relatif singkat. Penyebaran kuesioner ini merupakan mekanisme pengumpulan data yang efisien, karena kuesioner dapat dibagikan langsung, disuratkan, ataupun disebarkan melalui email kepada responden. Pengukuran kuesioner pada penelitian ini menggunakan Skala Likert, di mana skor yang diberikan pada setiap jawaban responden adalah :

a. Jawaban Sangat Setuju (SS) diberi skor 5

b. Jawaban Setuju (S) diberi skor 4

c. Jawaban Netral (N) diberi skor 3

d. Jawaban Tidak Setuju (ST) diberi skor 2

e. Jawaban Sangat Tidak Setuju (STS) diberi skor 1

Pengujian validitas dan reliabilitas adalah sebagai berikut. Uji validitas digunakan untuk mengukur sah atau valid tidaknya suatu kuesioner. Suatu kuesioner dikatakan valid jika pertanyaan pada kuesioner mampu untuk mengungkapkan sesuatu yang akan diukur oleh kuesioner tersebut. Teknik uji validitas yang digunakan dalam penelitian ini adalah teknik analisis faktor dengan bantuan software SPSS . Untuk mengukur tingkat interkorelasi antar variabel dan dapat atau tidaknya dilakukan analisis faktor menggunakan Kaiser Meyer Olkin Measure of Sampling Adequacy (KMO MSA) bila nilai KMO MSA lebih besar dari 0, 5 maka proses analisis dapat dilanjutkan. Validitas suatu butir kuesioner dapat diketahui jika nilai $\mathrm{KMO} \geq 0,5$. Bila terdapat nilai MSA yang kurang dari 0,5 maka variabel dengan nilai MSA terkecil harus dikeluarkan dan begitu seterusnya sampai tidak ada lagi nilai MSA yang kurang dari 0,5 .

Reabilitas dalah suatu alat ukur untuk mengetahui sejauh mana alat ukur dapat diandalkan secara konsisten. Hasil pengukuran dapat dipercaya apabila alat ukur memberikan hasil yang sama atau tidak berubah-ubah sekalipun pengukuran dilakukan berulang-ulang. Penghitungan reliabilitas dilakukan dengan menggunakan program statistik SPSS dan uji reliabilitas menggunakan teknik pengukuran Chronbach Alpha, hasil pengujian dapat dikatakan reliabel apabila Chronbach Aplha> 0. 6.

Uji normalitas bertujuan untuk menguji apakah dalam model regresi, data dalam penelitian mempunyai distribusi normal atau tidak. Pengujian ini dapat dilakukan dengan melihat profitabilitas dari Kolmogorov Smirnov Z statistik. Jika profitabilitas Z statistik lebih kecil dari 0,05 maka nilai residiual dalam suatu regresi tidak terdistribusi secara normal.

Uji hipotesis dalam penelitian ini menggunakan Uji Siginifikan Parameter individual ( Uji Sstatistik-t). Pengujian ini dimaksudkan untuk mengetahui apakah masing-masing variabel independen berpengaruh signifikan terhadap variabel dependen, dikatakan berpengaruh signifikan apabila sig $<$ a $(0,05)$. Pengujian ini dilakukan dengan tingkat kepercayaan $95 \%$ dengan ketentuan sebagai berikut: 
a. Jika thitung $>$ ttabel $(0,05)$, maka Ha diterima dan $\mathrm{H}_{0}$ ditolak.

b. Jika thitung $<$ ttabel $(0,05)$. maka Ha ditolak dan $\mathrm{H}_{0}$ diterima.

\section{HASIL DAN PEMBAHASAN \\ Karaktiristik Responden}

Hasil dari rekapitulasi karakteristik responden menunjukan perbandingan pada jenis kelamin responden, dimana jumlah responden laki-laki adalah seratus lima puluh sembilan orang dan seratus delapan belas merupakan responden perempuan.Perbandingan pada usia responden menunjukan bahwa empat puluh delapan responden dengan rentan usia dibawah 20-25 tahun, tujuh puluh tujuh responden berusia 26-30 tahun, sembilan puluh responden dengan rentan usia 31-35 tahun, dan sejumlah enam puluh dua responden berusia diatas 35 tahun. Perbandingan pada pendidikan terakhir responden menunjukan bahwa yang menjadi responden dalam penelitian ini berpendidikan sekolah menengah atas atau sekolah menengah kejuruan dengan jumlah seratus tiga puluh delapan responden, diploma tiga lima puluh dua responden, strata satu (S1) tujuh puluh dua responden dan pascasarjana (S2) sejumlah lima belas responden.

\section{Analisis Regresi Linier Berganda}

Analisis kuantitatif dilakukan untuk mengetahui pengaruh kontrak psikologis dan komitmen organisasi terhadap kinerja karyawan.menunjukan bahwa nilai konstan adalah sebesar 21,747, nilai kontrak psikologis (X1) sebesar 0,241, dan komitmen organisasi (X2) adalah sebesar 0,373 , berdasarkan nilai-nilai tersebut maka persamaan regresi liner berganda adalah sebagai berikut:

$$
\begin{gathered}
Y=a+b_{1} X 1+b_{2} X 2 \\
Y=21,747+0,241 X 1+0,373 X 2
\end{gathered}
$$

Persamaan fungsi regresi serta hasil koefisien regresi tersebut mencerminkan bahwa dalam penelitian ini setiap variabel $X$ (kontrak psikologis dan komitmen organisasi) memiliki pengaruh positif terhadap variabel $\mathrm{Y}$ (kinerja karyawan) dengan keterangan sebagai berikut:

a) Hasil koefisien regresi yang dimiliki variabel kontrak psikologis (X1) adalah sebesar nol koma dua ratus empat puluh satu. Hasil koefisien regresi yang dimiliki variabel variabel kontrak psikologis (X1) dalam penelitian ini menunjukan bahwa dua puluh empat koma satu persen variabel kinerja karyawan (Y) dipengaruhi secara positif oleh variabel kontrak psikologis (X1), hal ini berarti bahwa setiap kenaikan nilai variabel kontrak psikologis (X1) dapat menaikan nilai variabel kinerja karyawan (Y) sebesar nol koma dua ratus empat puluh satu.

b) Hasil koefisien regresi v ariabel komitmen organisasi (X2) adalah sebesar nol koma tiga ratus tujuh puluh tiga. Hasil koefisien regresi yang dimiliki variabel variabel komitmen organisasi (X2) memiliki arti bahwa tiga puluh tujh koma tiga persen variabel kinerja karyawan (Y) dipengaruhi secara positif oleh variabel komitmen organisasi (X2), hal ini berati setiap kenaikan nilai variabel komitmen organisasi (X2) dapat menaikan nilai variabel kinerja karyawan (Y) sebesar nol koma tiga ratus tujuh puluh tiga. 


\section{Uji Hipotesis (Analisis Uji T)}

Pengujian ini dimaksudkan untuk mengetahui apakah masing-masing variabel independen berpengaruh signifikan terhadap variabel dependen, dikatakan berpengaruh signifikan apabila sig < a $(0,05)$. Pengujian ini dilakukan dengan tingkat kepercayaan sembilan puluh lima persen dengan ketentuan sebagai berikut:

$>$ Jika thitung $>$ ttabel $(0,05)$, maka Ha diterima dan $\mathrm{H}_{0}$ ditolak.

$>$ Jika thitung $<$ ttabel $(0,05)$. maka Ha ditolak dan $\mathrm{H}_{0}$ diterima.

\section{Hasil Uji T}

Hasil analisis uji $\mathrm{t}$ yang menggunakan bantuan program statistik SPSS dan berdasarkan pada nilai ${ }_{\text {tabel }}$ menunjukan bahwa variabel $\mathrm{X}$ (kontrak psikologis dan komitmen organisasi) memiliki pengaruh positif dan signifikan terhadap variabel Y (kinerja karyawan).Penjelasan mengenai uji $\mathrm{t}$ (pengaruh variabel $\mathrm{X}$ terhadap variabel $\mathrm{Y}$ ) dapat dijelaskan sebagai berikut:

Hasil pengujian menunjukkan bahwa variabel kontrak psikologis memiliki t hitung sebesar empat koma seratus tiga puluh dengan tingkat signifikansi nol koma nol nol. Hal ini menunjukan bahwa t hitung $>\mathrm{t}$ tabel dengan taraf signifikansi lebih kecil dari nol koma nol lima yang berarti $\mathrm{H}_{0}$ ditolak dan Ha diterima. Hal tersebut berarti bahwa adanya pengaruh positif secara parsial dan signifikan antara variabel kontrak psikologis (X1) terhadap kinerja karyawan (Y) dengan tingkat pengaruh nol koma dua ratus empat puluh satu. Hasil penelitian ini sejalan dengan penelitian terdahulu yang dilakukan oleh Tsui et. al (2013) dimana hasil yang didapat adalah kontrak psikologis dan komitmen organisasi mempengaruhi kinerja karyawan secara positif.

Hasil pengujian menunjukkan bahwa variabel komitmen organisasi memiliki t hitung sebesar enam koma tiga ratus sembilan puluh lima dengan tingkat signifikansi nol koma nol nol. Hal ini menunjukan bahwa t hitung $>t$ tabel dengan taraf signifikansi lebih kecil dari nol koma nol lima yang berarti $\mathrm{H}_{0}$ ditolak dan Ha diterima. Hal tersebut berarti bahwa adanya pengaruh positif secara parsial dan signifikan antara variabel komitmen organisasi (X2) terhadap kinerja karyawan (Y) dengan tingkat pengaruh nol koma tiga ratus tujuh puluh tiga. Hasil penelitian ini sejalan dengan penelitian terdahulu yang dilakukan oleh Tsui et. al (2013) dimana hasil yang didapat adalah kontrak psikologis dan komitmen organisasi mempengaruhi kinerja karyawan secara positif.

\section{KESIMPULAN \\ Kesimpulan}

Kesimpulan dan rekomendasi dari penelitian ini dapat disimpulkan bahwa psikologis (X1) dan komitmen organisasi (X2) terhadap kinerja karyawan (Y) pada PT. Sari Segar Husada bahwa : (1)Hasil koefisien regresi linier berganda dan uji $\mathrm{t}$ ( $\mathrm{t}$ hitung $>\mathrm{t}$ tabel) menunjukkan bahwa $\mathrm{H}_{0}$ ditolak dan $\mathrm{Ha}$ diterima, sehingga variabel kontrak psikologis mempengaruhi tingkat kinerja karyawan secara positif dan signifikan sebesar nol koma duaratus empat puluh satu. (2)Hasil koefisien regresi linier berganda dan uji $t$ (t hitung $>t$ tabel) menunjukkan bahwa $\mathrm{H}_{0}$ ditolak dan $\mathrm{Ha}$ diterima, sehingga variabel komitmen organisasi mempengaruhi tingkat kinerja karyawan secara positif dan signifikan sebesar nol koma tiga ratus tujuh puluh tiga.

\section{Limitasi dan studi Lanjutan}

Penelitian ini memiliki keterbatasan atau kekurangan yang perlu diperbaiki dalam penelitian-penelitian kedepannya, karena hakekatnya penelitian ini diharapkan dapat menjadi acuan dalam penelitian selanjutnya ataupun sebagai pendukung untuk penelitian lainnya. Keterbatasan atau kekurangan tersebut ialah, penelitian ini hanya terfokus untuk 
melihat bagaimana pengaruh kontrak psikologis dan komitmen organisasi sebagai variabel $\mathrm{X}$ terhadap kinerja karyawan sebagai variabel $\mathrm{Y}$, tanpa membahas variabel lain diluar penelitian yang berpotensi untuk mempengaruhi kinerja karyawan. Saran dlihat dari hasil dan pembahasan maka diperoleh beberapa saran yang peneliti ajukan dan dapat dijadikan acuan, diantaranya Perbaikan pada bagian kontrak psikologis dalam organisasi ataupun perusahaan dapat dengan menumbuhkan kepercayaan ataupun keyakinan melalui motivasi kepada karyawan bahwa bekerja dengan baik adalah kewajiban dari setiap karyawan.Perusahaan dapat mengupayakan peningkatan komitmen organisasi pada setiap karyawan dengan memacu dan memotivasi karyawan, serta menumbuhkan rasa solidaritas dalam perusahaan sehingga dapat memacu karywan untuk tetap mempertahankan karyawan berkompeten dalam perusahaan.Peningkatan kinerja karyawan dapat dengan motivasi dan menumbuhkan lingkungan kompetisi dalam perusahaan dimana dapat memicu karyawan bekerja dengan optimal dan meminimumkan kesalahan dalam pekerjaan.

\section{Refrensi}

Allen \& Meyer. 1991. The Measurement And Antecedents Of Affective, Continuance And Normative Commitment to The Organization. Great Britain. Journal Of Occupational Psycholog, 63, 1-18.

Allen dan Meyer. (1997). Commitment in The Workplace Theory Researchan Application. California: Sage Publications

Chaoping, L., Jiafang, L. and Yingying, Z. 2013. Cross Domain Effect Of Work Family Conflict On Organizational Commitment And Performance. Social Behavior and Personality.Vol. 41. No.10.16411654.

Koopmans, L., et al. 2014. Construct Validity of Individual Work Performance Questionaire. Journal of Occupational and Environmental Medicine. Volume 56, Number 3. Pp. 331-337

Mathis, R. L. \& Jackson, J. 2006. Manajemen Sumber Daya Manusia. (Jimmy Sadeli \& Bayu Prawira Hie, Penerjemah). Jakarta: Salemba Empat.

Rousseau, D.M. \& Schalk, R. 2000. Psychological Contracts in Employment: Crossnational Perspectives. Newbury Park, CA: Sage, In Press.

Schein, E. H. 2010. Organizational Culture and Leadership (4th ed.). San Francisco, CA: Jossey-Bass.

Tsui, P. L. et. al. 2013. The Influence Of Psikological Contract and Organizational Commitment On Hospitality Employee Performance. Social Behavior and Personality, 443-452. 